This item was submitted to Loughborough's Research Repository by the author.

Items in Figshare are protected by copyright, with all rights reserved, unless otherwise indicated.

Elected representatives, online self-presentation and the personal vote: party, personality and webstyles in the United States and United Kingdom

PLEASE CITE THE PUBLISHED VERSION

http://dx.doi.org/10.1080/13691180802025681

PUBLISHER

(C) Taylor and Francis

VERSION

AM (Accepted Manuscript)

LICENCE

CC BY-NC-ND 4.0

REPOSITORY RECORD

Stanyer, James. 2019. "Elected Representatives, Online Self-presentation and the Personal Vote: Party, Personality and Webstyles in the United States and United Kingdom". figshare.

https://hdl.handle.net/2134/13824. 
This item was submitted to Loughborough's Institutional Repository (https://dspace.lboro.ac.uk/) by the author and is made available under the following Creative Commons Licence conditions.

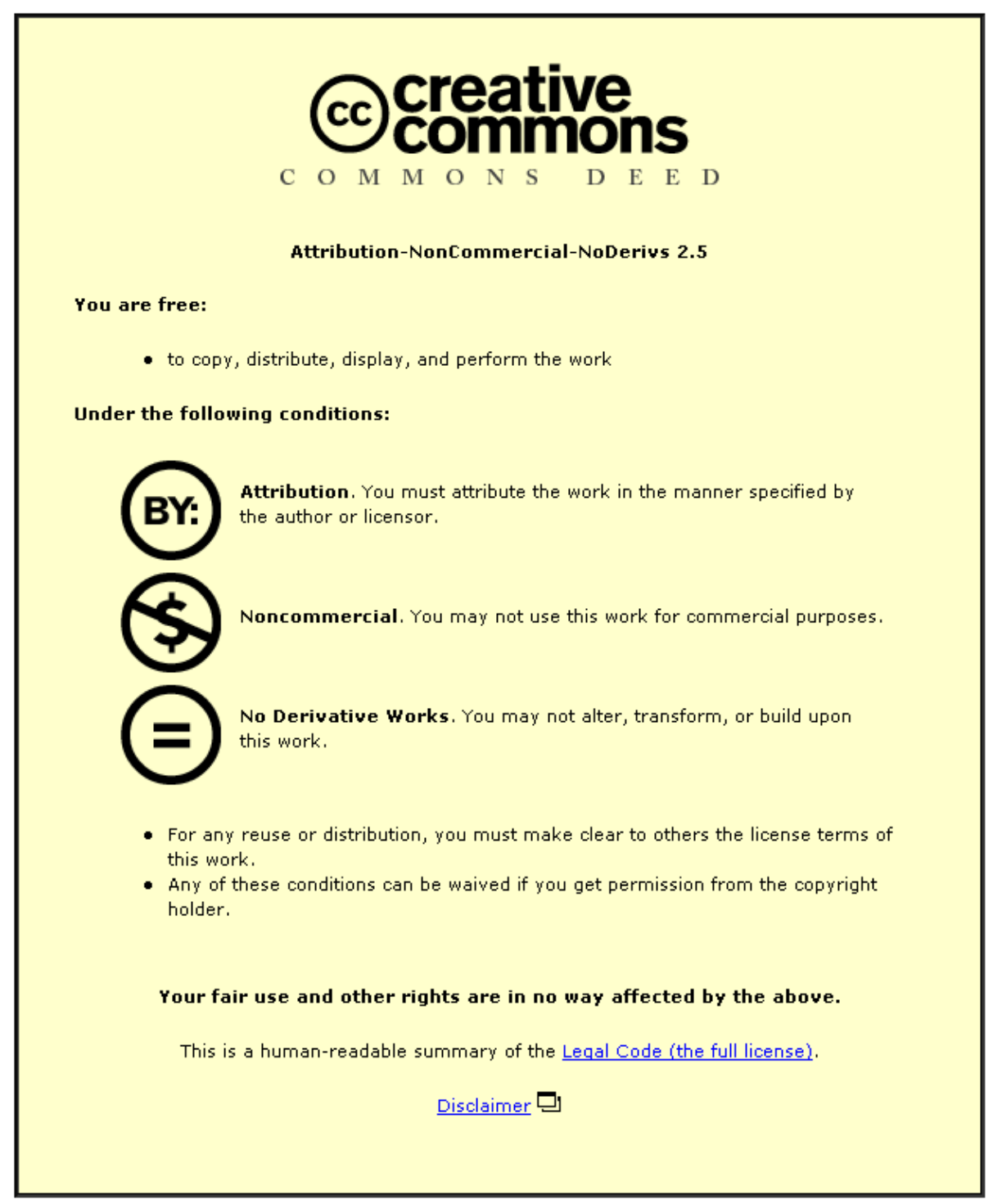

For the full text of this licence, please go to: http://creativecommons.org/licenses/by-nc-nd/2.5/ 
(2008) Information, Communication and Society Vol. 11, 3, pp. 113-131.

\title{
Elected Representatives, Online Self-Presentation and the Personal Vote: Party, Personality and Webstyles in the United States and United Kingdom ${ }^{1}$
}

\begin{abstract}
This article examines the way politicians package themselves to their constituents via the Web. It looks at various aspects of online self-promotion by incumbent representatives in two advanced industrial democracies - the US and the UK. It seeks to ascertain the extent to which personal qualities are a key aspect of an elected representative's online persona, and any differences that exist between these democracies with different electoral cultures. It concludes by considering the findings of empirical research and what it reveals about the relationship between national electoral cultures and the politician's persona.
\end{abstract}

\section{Keywords}

Elected representatives, homepage, online impression management, online persona, personalisation, websites, webstyle 
There are growing claims that a new personalised political culture is emerging across a range of different advanced industrial democracies (see for instance, Corner 2000; Corner and Pels 2003; Street 2003). It is argued that this personalised culture is not only well established in presidential political systems, where individuals compete for high office, but also in parliamentary systems (see Mughan 2000). For example, in parliamentary democracies, party leaders have assumed an increasingly central position in parties' campaigns for office and they have come to embody their respective parties (for a synoptic account see McAllister 2007). A growing number of observers suggest that one of the key factors contributing to the personalisation has been electronic communication technologies such as television, and more recently the Web (Mughan 2000; Gulati 2004).These technologies have transformed the visibility of political actors, rendering them visible to a mass audience of non co-present citizens. Others have pointed to another factor, namely an increasingly de-aligned electorate that makes judgments based on personal factors; as Corner and Pels observe, 'people want to vote for people and their ideas rather than for political parties and their programs' (2003: 7). They argue that the claims of politicians are scrutinized for authenticity by an electorate that is increasingly visually and emotionally literate. The choice of who to vote for, out of the continually visible political actors, is related to an audience's reading of a politician's style (Pels 2003; Street 2003). For others, it is not so much a case of the electorate's visual and emotional literacy but the need to decide who out of the candidates available is most competent to govern. Although there is much debate about the extent to which choices are shaped by personal attributes and style (for a synoptic account see King 2002), there is a growing view that electoral judgments in some mature democracies are increasingly based on personal non-policy factors rather than purely programmatic ones (Clarke et al. 2004; Kendall and Paine 1995; Hacker 1995). 
The emergence of a personality-focused electorate means that effective selfprojection through the media is increasingly essential for building a bond with voters, and ensuring electoral success (Corner and Pels 2003). A growing number of studies examining strategic self-presentation by politicians, in various democracies, reveal the growing emphasis placed on projecting the right image in the media (Allum and Cilento 2001; Corner 2000; Pels 2003; Gulati 2004; Schutz 1995). Research has shown that US presidential candidates increasingly use certain media channels to emphasize personal qualities when campaigning (Hellweg 1995; Davies 1999). For instance, chat shows have become an important destination for presidential hopefuls. The first appearance of a candidate on a chat show came in the 1960 US presidential campaign, when both John F. Kennedy and Richard M. Nixon were guests on Jack Paar's show. By the 1992 US presidential campaign, the television chat show had become a routine campaign stop. Recent research in Europe shows that party leaders increasingly use various media outlets to emphasize the qualities that they believe their constituents see as positive (Allum and Cilento 2001; Campus 2002; Cockerell 1989; Mughan 2000; Pels 2003). For example, research conducted on politicians on television talk-shows found that their self-presentation 'consisted of pointing out their belief in moral values as well as their worthiness, which was paired with selfdisclosure [...]. In addition, politicians presented knowledge as well as past successes or innovative ideas, behaviors that may be aimed at establishing impressions of competence' (Schutz, 1995: 219). They sought to appear as 'a likeable, trustworthy, and competent person, who is sincere in promising changes for the better, as well as capable of bringing about these changes' (Schutz 1995: 219).

While much of the focus has been on the media appearances of leading politicians on national television or in the national press, it is not only these actors who engage in public acts of impression management. Elected representatives use a 
range of media outlets to project an appealing image of themselves to their constituents. The Web is one increasingly important outlet that they use to project their persona (Banwart and Kaid 2002). In the US, Gulati (2004) found that House members and Senators used a mixture of symbols and images to portray themselves as either 'Washington insiders', who have influence, or 'outsiders', who are in touch with their constituents. Research by Jarvis and Wilkerson (2005) revealed nearly all House members' websites contained a biography and these, in the main, were used to trumpet their accomplishments and professional success. Research by Bimber and Davis, in 2000, found that home pages emphasized a candidate's appealing traits, qualifications, family relations, and, further, were used to try to highlight a common bond with voters and appear empathetic to their concerns (2003). In the UK, research found that over $90 \%$ of MPs' home pages sampled displayed information about themselves and their families (Ward and Gibson 2003). Other research on MPs' websites revealed that a majority of those sampled were used for self-promotion, detailing what the representatives were doing on behalf of their constituents (Jackson and Lilleker 2004). In sum, research based on national case studies has shown that politicians, in different democracies, employ time and resources in using the media and the Web to produce an electorally advantageous impression.

However, while it is undeniable that changes have taken place, the assumption is that the new personalised political culture that has emerged is largely uniform across different mature democracies; differences in the extent of personalisation in these democracies are under-explored. Although the politics is indeed mediated, there may still be significant differences in the levels of personalisation (see Campus 2002). For example, one difference that exists is the strength of the personal vote in relation to the party vote in respective electoral systems. In the US, for instance, the electoral significance of the party label has declined fairly dramatically, whereas in other 
democracies, in comparison, voter choice is still first and foremost between parties and not between candidates (Norris 2000). So while there has been a gradual erosion of traditional partisan ties between voters and parties, this has occurred to a greater extent in some democracies than in others.

These differences may mean that strategic self-promotion is more advanced in one particular mature democracy rather than another, or develops in a particular way in one country but in a different way in another. Such a comparison reminds us that mediated political cultures have national characteristics, which may influence the projection of political persona. There is a need for a fuller understanding of the relationship between mediated self-promotion and national political cultures. It could be that the strength or weakness of the personal vote may act either as a brake or an aid to the personalisation process.

This article, albeit in a limited way, explores mediated self-presentation in two democracies with different political cultures - the US and the UK. It looks at the latest medium through which all politicians can project an image of themselves: the World Wide Web. It starts by exploring online self-presentation. It then examines the extent to which a representative's personal qualities are a key element of his or her website. It then considers the findings of empirical research on the projection of personal qualities on websites, considering what it reveals about the relationship between mediated self-promotion and national political cultures.

\section{Impression management online}

Politicians engage in self-promotion using different media outlets. While not the most important communication outlet, all parties and politicians increasingly utilize the World Wide Web (Gibson and Ward 2000; Margolis et al. 2001). Representatives in most post-industrial democracies maintain a permanent Web presence (see the 
parliament online database for instance). ${ }^{2}$ In the US, members of both houses of Congress have had websites since the mid-1990s. In 2003, 68\% of Senators and 52\% of House representatives had a 'live' (regularly updated) website (Gulati 2004); in 2007 all House members had a website. In the UK, in 1998, 4\% of the 646 MPs had live websites (Ward and Gibson 2003); by 2007, 75\% had a website, the majority being regularly updated. ${ }^{3}$

The website offers elected representatives a space to present themselves to their constituents. The website, to use Goffman's phrase, constitutes another 'front region' in which representatives disclose information about themselves that would not necessarily be exposed to another in a face-to-face encounter. It is a space that lends itself to effective self-presentation (Döring 2002). As Miller notes, the Web is a particularly good outlet 'for us to display ourselves and make claims about ourselves' (1995: 8). This is not to argue that the personal website replaces face-to-face contact, the local news media, or other outlets, but, in the era of the large constituency numbering many thousands, the Web provides politicians with a means of establishing and maintaining a presence amongst their constituents; it supplements the already established means of self-presentation. This is especially the case in the US where an artificial cap on the number of House representatives means an everexpanding number of constituents. It is estimated that the current ratio of 400,000 constituents to each representative will grow to 600,000 to 1 in 20 years. In such a situation, the website will be an important point of first contact between the elected representative and the constituent.

This additional channel also allows representatives to disclose a large amount of detailed information which might be useful for their constituents, but which journalists may not consider newsworthy, or may be impractical to impart face-toface. It is also a channel where representatives have editorial control and can 
determine the nature of that information and the length of time it is available to the public (Davis 1999; Ward and Gibson 2003). As Döring observes of the website, 'we can present ourselves more deliberately, more selectively... than in face-to-face scenarios, and are not placed under intense pressures of confrontation and pressures to act' (2002: 9). The website can be seen as a cost-efficient self-advertisement, where representatives are free to construct and present an image of themselves (StromerGalley 2000). In sum, while in some democracies there are rules that prevent the use of official resources for campaigning, the sites remain important channels through which representatives present an image of themselves throughout a parliamentary term (Carter 1999; Gulati 2004; Johnson 2004; Jarvis and Wilkerson 2005; Ward and Gibson 2003).

It is argued that impression-management online draws heavily on established printed forms of presenting the self, such as the curriculum vitae (Miller 1995, 1998). As with the curriculum vitae, each representative's website seeks to establish his or her identity. The representative's identity is revealed through their name, appearance and biography. This information is enhanced with disclosures that emphasize the qualities that the representative possesses, qualities that make him or her suitable for the job (see Jarvis and Wilkerson 2005; Ward and Gibson 2003). A key function of the website is the provision of evidence to support the claims made: the representative does not only have to be hard working to protect their seat, but also appear to be hard working - and provide the evidence. Websites allow representatives to remind their constituents that they are 'effectively represented' in the words of one MP, 'that people know that you are doing things on behalf of that area' (Lilleker and Negrine 2003: 70; see also Jackson and Lilleker 2004). The impression a representative seeks to generate online to non co-present constituents, while different, is not inconsistent with the impression he or she seeks to generate in interacting with the public (Gulati 
2004). They will seek to project the same identity (they will not appear as someone else) and emphasize the same qualities, albeit in a different way. However this said, the nature of the medium means that the online persona is static and passive, unlike in the media studio or public place; it does not respond in real time to audience reaction. Disclosure of information is carefully managed to influence the impressions audiences construct. Politicians are continually seeking to create the right impression amongst an audience, whether a specific group or a nation as a whole. They seek to establish a connection with their audience by providing this unknown other with information that they believe will show that they embody the desirable characteristics of political leadership (Sigelman, 2001). As nearly all representatives desire reelection $^{4}$, they are likely to say not only who they are, but also disclose information on their websites that presents a favourable impression and emphasizes key qualities in order to secure this goal. As identity is revealed through name, photograph and biography, the selection of the photograph and the information contained within a biography is carefully made. Research off-line shows that politicians pursue a strategy of 'selective projection', emphasizing their assets and de-emphasizing their liabilities to help ensure re-election (Medvic 2001: 51). To borrow the words of the sociologist Erving Goffman, the politician is interested in 'expressing himself in a given way in order to give a kind of impression to others that is likely to evoke from them a specific response he is concerned to obtain' (1990: 17); the 'specific response' in this case being electoral support. The choice of which qualities are emphasized is not random but based on their experience over time (Mayhew, 1974), and, increasingly, on market research (Medvic 2001). Any perceived liabilities that might compromise the image are kept secret, out of the public glare in the 'back regions'. Indeed, politicians may go to extraordinary lengths to conceal information that might undermine the impression 
that they are trying to generate, as the example of President Clinton's affair with Monica Lewinsky shows (see Schudson, 2004).

An incumbent seeking re-election will seek to project a combination of favourable traits (Schutz 1995). Studies carried out in the US on Congressmen and women found that incumbents sought to emphasize 'qualification, identification and empathy' (Fenno 1978: 57). Representatives have to give the impression that they are qualified for the position, have a common bond with the constituents and care about and understand their constituents' concerns (Fenno 1978). Mayhew observes they seek to accentuate personal qualities such as 'experience, knowledge, responsiveness, concern, sincerity, independence' (1974: 40). For Jacobson, the House member who emphasizes their common bond, is a 'member who is trusted, accessible, and thought to be "one of us" ' and in general will have much less trouble defending their seat (1997: 74). Davies echoes some of these findings, noting that House members take every opportunity to present 'themselves to their voters as a friend and individual protector of the constituency generally as well as of the individual citizens' (1999: 176). In the UK, research has pointed to MPs developing a 'constituency style' (Power 1998). Norton and Wood (1993) and Radice et al. (1987) found that MPs seek to present themselves as active in the constituency, serving the constituents' needs, and as busy at Westminster, serving on committees, bringing forward legislation, taking on ministerial roles.

These qualities will be emphasized via the selective disclosure of evidence online. For instance, the website of a representative wanting to show that he or she is qualified or empathetic will not usually crudely pronounce ' $\mathrm{x}$ is a well qualified and kind hearted man or woman' but demonstrate these qualities through disclosing information about his or her legislative activity, and his or her work in the constituency, and community service. Similarly, a representative may seek to 
demonstrate that he or she is 'honest' by disclosing online that he or she has fulfilled his or her campaign pledges. The websites of representatives are therefore full of descriptions about the activities of their host, with the intent of generating the desired positive impression. While many qualities can be emphasized by the disclosure of information on a representative's activities in office, it is worth mentioning that the political self is also constructed through the selective disclosure from private life. As Corner notes, 'there is ample evidence that the private sphere is being used as a resource in the manufacture of political identity' (2003: 76; see also Schutz 1995). So, for instance, a candidate's localness is evidenced through revealing personal information about his or her place of birth or the area where he or she was raised. The representative does not literally need to state that he or she is connected to the locale, but the disclosure of such information shows this. Websites provide pictorial and written evidence to generate particularly positive perceptions of the representative. The representative lets voters know that he or she has the qualities they desire by carefully disclosing information from his or her public and private life. These disclosures play an important part in the electorate getting to know the incumbent, and of being able to identify with him or her.

\section{Webstyles and the personal vote}

While acknowledging the growing projection of personal qualities by politicians in different countries, it is easy to slip into a 'naive universalism' (Blumler and Gurevitch 1995) which glides over the national context, arguing that driven by the desire to be re-elected, incumbent representatives in all democracies will emphasize similar qualities on their websites. A necessary antidote is provided by comparative research, which explores online self-presentation by politicians in two or more countries. Such research might show that self-presentation is indeed similar, but it 
might also throw-up national differences. For instance, take the comparison between the US and the UK. While the projection of the right personal qualities is important to the electoral appeal of politicians in both countries, national factors, such as the electoral significance of individual candidates compared to political parties, means that the trend towards the promotion of the self might be more advanced in the US than the UK. ${ }^{5}$ As Jacobson observes, 'from the 1950s through to the 1980s, the electoral importance of individual candidates and campaigns expanded, while that of party labels and national issues diminished' (1997: 19). Further, Wattenberg notes that, in the US, parties and candidates are less tightly linked in public perceptions than at any time previously. Candidates have become largely disassociated from parties with the positions they adopt '-no longer linked to voters' perceptions of the parties' (Wattenberg 1996: 81).

As a House representative's support is largely personal, he or she has to maintain a personal presence amongst the constituents to ensure support (see Cain $e t$ al. 1987). Jacobson notes that familiarity is important for voters in Congressional elections: 'the more familiar voters are with a candidate, the more likely they are to vote for him or her... Only $4 \%$ of House voters defected to candidates who were less familiar than their own' (1997: 95). In the UK, the de-coupling of party and candidate has not occurred to anywhere near the same extent. At a general election, voters still very much vote for the MP because he or she is a representative of a party - this does not mean that there will not be a personal appeal in some constituencies, estimated by some to be up to 1500 votes (Radice et al. 1987). However, as Norton and Wood (1993) and Radice et al. (1987) note, MPs may enjoy a personal vote, but not to the same extent as their US counterparts. For the British voter the choice is first and foremost between parties, and not between candidates as in the US (Norris 2000). 
One could hypothesize that, given the relative weakness of the personal vote and strength of the party vote, the projection of personal qualities by MPs on their websites will be on a smaller scale than in the US. The next section seeks to examine this hypothesis. It is interested in the extent to which the scale of the personal vote shapes this relatively new means of self-presentation. The analysis focuses on the personal websites of House members and MPs in April 2005. It looks at the similarities and differences in the way incumbent representatives present themselves on their websites. It is interested to see whether their webstyles (see Banwart and Kaid 2002) will be largely similar or whether they will differ between a political system with a strong personal vote and one with a weaker personal vote and a stronger party vote, and in what way.

\section{Methods and study design}

The importance and problems of conducting cross-national comparative research have been well documented (Blumler et al. 1992; Gurevitch and Blumler 2004;

Livingstone 2003; Peters 1998). This article argues that despite these problems, one can only understand the extent to which the national electoral environment shapes webstyles through effective comparative research. The evidence presented in this article is based on a content analysis of the personal websites of MPs and House members. The content analysis focused on the identity that representatives sought to project and the qualities they sought to emphasize. Based on the literature, a list of desirable qualities that representatives might seek to project was drawn up (see Fenno 1978; Jarvis and Wilkerson, 2005; Mayhew 1974; Power, 1998; Radice et al., 1987). From this, a shortlist of key positive qualities was made, the content of which was discussed amongst colleagues. These traits were: warm and friendly, hardworking, 
knowledgeable and experienced, caring and concerned, and in touch. An initial sample of ten sites was then examined while the literature was being reviewed.

One key issue that arose during this initial examination concerned the interpretation of evidence. For instance, what information would a politician disclose to project the impression of being personable? After further discussion with colleagues, it was decided that, given the nature of the medium, such an impression could be created by the inclusion of a greeting or formal introduction on the website. Likewise, it was agreed that other desirable empathetic qualities, such as caring and concern, for instance, would be demonstrated through the disclosure of information on the representative's involvement in community projects, or with charities, or the sick and needy. However, it should be noted that such a process was far from an exact science; while the emphasis of some qualities was fairly straightforward, others proved problematic. A list of desired traits and the manner in which the evidence was most likely to be disclosed was drawn up and tested against a small sample of ten websites. In addition to those already mentioned above, the following qualities were considered to be emphasized by the evidence listed. The trait of being hardworking was indicated by disclosure of information on achievements, and legislative and community involvement advertised in a news section and elsewhere on a website. Knowledge and experience was indicate by the disclosure of information on education, work experience - whether in post or not - and awards gained in office. Being in touch was indicated by disclosure of information on community involvement, local roots and family.

A content analysis schedule was then developed including these key traits. A sample of 100 websites was selected from an alphabetical list - 50 from each country - and weighted to take account of the different political parties. Intercoder reliability was an important consideration in establishing the trustworthiness of any variables. 
Once the content analysis sheet was developed, a further small sample of five websites was examined by a colleague and the author, and results compared. The results showed an $80 \%$ agreement, the discrepancies were re-examined and agreement reached before the survey of sites began. The data was then analyzed using computer statistical software package SPSS.

\section{Results and Discussion}

In both countries self-presentation online was well established: of 435 House members all had websites, but not all of the 646 MPs had sites that could be accessed. ${ }^{6}$ The results show both similarities and differences in online selfpresentation by representatives. Not surprisingly the name and photograph of the representative was prominently displayed on the vast majority of websites in both countries $-98 \%$ in the US and $96 \%$ in the UK. These photographs were almost exclusively 'mug shots' of the representatives; what Jarvis and Wilkerson term 'suitand-tie headshot' (2005: 10).

[Table 1 about here]

There was a genuine attempt by both sets of representatives to appear approachable, warm and friendly. The majority of sites $-54 \%$ in the US and $70 \%$ in the UK contained a greeting of one form or another. However, as table 2 shows, it was mainly House members that sought to offer constituents the opportunity for further interaction in the form of regular information updates.

[Table 2 about here] 
In sum, both groups of representatives wanted to project a personable and friendly image. The difference in approach was that the US House members placed less emphasis on a written welcome and were more interested in developing a closer connection through, for instance, getting constituents to subscribe to a regular news letter.

[Table 3 about here]

Both sets of representatives were keen to be seen as dedicated to serving their constituents and active and working hard in the legislature. Table 3 shows that the majority of websites sampled in both countries presented a list of the representatives' achievements; US representatives, though, were more eager to trumpet their achievements. This was done in the form of a latest information or news section. The news section was a more prominent part of US representatives' sites than of UK MPs', with 32\% more sites listing achievements.

In addition, both sets of representatives were keen to emphasize their committee and legislative involvement. Overall though, House members placed slightly more of an emphasis on being committee members and on their legislative activities compared to their UK counterparts.

[Table 4 about here]

There was a fairly universal attempt by both sets of representatives to emphasize their qualifications; this included their academic achievements and or relevant experience in politics or business, as table 5 shows. 
[Table 5 about here]

However, as table 6 shows, only a minority mentioned any awards and honours they had received.

[Table 6 about here]

Both sets of representatives sought to project themselves as caring and concerned members of the community. Table 7 shows the majority of sites in both countries $88 \%$ in the US and $76 \%$ in the UK - provided evidence of the representatives' constituency activity, outlining what they were doing, and what they had done.

[Table 7 about here]

So in terms of the projection of personal qualities, both samples sought to present themselves as personable/friendly, knowledgeable, and approachable: people that were not only dedicated to the job, hardworking and effective but also concerned about local issues. However, there was a difference in the extent to which each sample emphasized these traits. If we summarize the comparison between House members and MPs, 32\% more Congress men/women emphasized their personal achievements, $26 \%$ more emphasized their legislative activity, $18 \%$ more their qualifications and experience, and $12 \%$ more their constituency involvement. The House members clearly placed more emphasis on being seen as hardworking and dedicated to the job, but did not place significantly more emphasis on being seen to be knowledgeable and experienced, in touch with constituents and effective - getting things done on behalf of their constituents. 
The differences between the two samples were more marked though when it came to identification, namely connecting with the constituents.

[Table 8 about here]

In the US, the representatives' biographies emphasized their local roots: $78 \%$ of the US sample mentioned their local ties, through schooling or family connections; this compared to only $28 \%$ of the UK sample. Congressmen and women were keen to present themselves as not only working for the community, but historically part of that region or community - however weak sometimes the link. In the UK, this latter emphasis was much less pronounced, and even where MPs mentioned a local connection, it tended not to be as prominent as in the US. The MPs' websites might be a reflection of a wider trend. Rush observes that in the UK the incidence of direct connection between MPs and their constituencies - by birth, education, living, working, property interests - fell from $57 \%$ in 1868 to $25 \%$ in 1979 , before rising to 45\% in 1997 (Rush 2001: 204).

Further, US representatives emphasized their family and background to a greater extent than in the UK $-90 \%$ of representatives' sites provided information on their family compared to $58 \%$ in the UK.

[Table 9 about here]

Although, not coded for, and unlike their UK counterparts, there seemed to be no mention by House members of divorce, re-marriage, or unmarried partners. This perhaps says something about the type of family background House members wanted to hide. 
The MPs' attempt to project a persona that their constituents could identify with revolved around their party identity.

[Table 10 about here]

In the UK, $78 \%$ presented themselves as part of a party, compared to only $4 \%$ in the US. Such a finding should not be regarded as a quirk of the sample. There are no restrictions preventing the display of partisan symbols on House members' websites (see Jarvis and Wilkerson 2005), and Jarvis and Wilkerson's (2005) study of a much larger sample of 118 House members' home pages, found that only 17\% exhibited any overt party identification, a relatively small proportion. In the UK, unlike the US, it was common for MPs' websites to raise their party's achievements in the constituency, in addition to the incumbents' accomplishments, particularly when their party was the party of government, or ran the local council. Party symbols were also prominent on the majority of the websites sampled. In the UK, the representatives' party identity is very much to the fore on their sites: they are a Conservative MP, a Labour MP, or Liberal Democrat - that is a key element in the identity they project. In contrast, in the US, local connections and family were much more prominent aspects of the House member's online persona.

\section{Conclusion}

This exploratory research, comparing the way incumbents present themselves to their constituents via their websites, has produced some mixed results. On the one hand, it has shown that elected incumbents, in both candidate- and party-centred systems, do seek to project certain analogous personal traits online. In both countries, similar proportions attached importance to being seen as knowledgeable and experienced, in 
touch with constituents, and effective representatives. On the other hand, the research has highlighted that incumbents in candidate-centred systems tend to emphasize local connections and family to a much greater extent than those in party-dominated systems, who are more likely to highlight party symbols and affiliations.

Differences in the strength of the personal vote can therefore be seen as a factor in shaping certain aspects of online self-presentation. In a candidate-centred electoral system with a strong personal vote, like the US, elected representatives cannot rely on party loyalties, and so their websites do not project an overt party identity but, instead, focus on projecting personal qualities and establishing a persona that resonates with the local electorate and ensures support. As Davies notes of the US, 'in a political system where party affiliation is only a limited guide to people's voting behaviour, the office holders have to establish alternative touchstones of loyalty' (1999: 178). A House member's key 'alternative touchstone' is being seen to be a married family man or woman with local roots, in addition to being seen to possess the other desirable personal qualities. In a party-dominated system, like the UK, with relatively weak personal loyalties, the incumbent's website has to remind the constituent of his or her party identity. However, even in a system with strong party loyalties, the projection of personal qualities was not totally absent. A very high proportion of MPs provided evidence of constituency involvement. Cultivating personal support could be seen as strategy to develop protection from a national swing against the incumbent's party (see Power, 1998). Of course it should be stated that other factors, such as the marginality of the district/constituency or the frequency of electoral contests, may enhance or weaken the need for representatives to establish personal touchstones of loyalty, but these remain to be tested. In sum, online selfpresentation is indeed shaped by the desire to be re-elected, which is the same for both 
sets of representatives, but it also reflects the wider importance of the personal vote or the party vote to achieving that ambition in each country.

\section{References}

Allum, F. and Cilento, M. (2001) 'Parties and Personalities: The Case of Antonio Bassolino, Former Mayor of Naples', Regional and Federal Studies, 11 (1): 1-26.

Banwart, M. C. and Kaid, L. L. (2002) 'Videostyle and Webstyle in 2000: An Interchannel Comparison of Candidate Self-presentation', a paper presented at the American Political Science Association annual conference, 30 August - September 3, Boston, MA.

Bimber, B. and Davis, R. (2003) Campaigning Online: The Internet in US Elections, Oxford: Oxford University Press.

Blumler, J. G. and Gurevitch, M. (1995) The Crisis of Public Communication, London: Routledge.

Blumler, J. G., McLeod, J. M. and Rosengren, K. E. (1992) ‘An Introduction to Comparative Communication Research', in J G. Blumler, J M. McLeod, and K E. Rosengren (eds.) Comparatively Speaking: Communication and Culture Across Space and Time, London: Sage.

Cain, B., Ferejohn, J. and Fiorina, M. (1987) The Personal Vote: Constituency Service and Electoral Independence, Cambridge, MA: Harvard University Press. Campus, D. (2002) 'Leaders, Dreams and Journeys: Italy's New Political Communication', Journal of Modern Italian Studies, 7 (2): 171-191.

Carter, M. (1999) 'Speaking Up in the Internet Age: Use and Value of Constituent Email and Congressional Websites', Parliamentary Affairs 52 (4): 464-479. Cockerell, M. (1989) Live From Number Ten, London: Faber and Faber. 
Corner, J. (2000) 'Mediated Persona and Political Culture: Dimensions of Structure and Process', European Journal of Cultural Studies, 3 (3): 386-402.

Corner, J. (2003) 'Mediated Persona and Political Culture', in J. Corner and D. Pels (eds.) Media and the Re-styling of Politics, London: Sage.

Corner, J. and Pels, D. (2003) 'Introduction: The Re-Styling of Politics', in J. Corner and D. Pels (eds) Media and the Re-styling of Politics, London: Sage.

Clarke, D. H., Sanders, D., Stewart, M. and Whiteley, P. (2004) Political Choice in Britain, Oxford: Oxford University Press.

Davies, P. J. (1999) US Elections Today, Manchester: Manchester University Press.

Davis, R. (1999) The Web of Politics: the Internet's Impact on the American Political System, New York: Oxford University Press.

Döring, N. (2002) 'Personal Home Pages on the Web: A Review of Research', Journal of Computer Mediated Communication, 7 (3): 28 pp.

http://www.ascusc.org/jcmc/vol7/issue3/doering.html

Fenno, R. F. (1978) Home Style: House Members in their Districts, Boston, MA:

Little Brown and Co.

Gibson, H. and Ward, S. (2000) 'UK Political Parties and the Internet: Politics as Usual in the New Media', Harvard International Journal of Press/ Politics, 3 (3): 1438.

Goffman, E. (1990 [1959]) The Presentation of Self in Everyday Life, London: Penguin.

Gulati, G. J. (2004) 'Members of Congress and Presentation of Self on the World Wide Web', Harvard International Journal of Press/ Politics, 9 (1): 22-40.

Gurevitch, M. and Blumler, J. G. (2004) State of the Art of Comparative Political Communication Research: Poised for Maturity? in F. Esser and B. Pfetsch (eds.) 
Comparing Political Communication: Theories, Cases and Challenges, Cambridge:

Cambridge University Press.

Hacker, K. L. (1995) 'Introduction: The Importance of Candidate Images in

Presidential Elections', in K L. Hacker (ed.) Candidate Images in Presidential

Elections, Westport, CT: Praeger.

Hellweg, S. A. (1995) 'Campaigns and Candidate Images in American Presidential

Elections', in K L. Hacker (ed.) Candidate Images in Presidential Elections, Westport, CT: Praeger.

Jackson, N. A. and Lilleker, D. G. (2004) 'Just Public Relations or An Attempt at Interaction', European Journal of Communication, 19 (4): 507-533.

Jacobson, G. C. (1997) The Politics of Congressional Elections, 4th edn, New York: Longman.

Jarvis, S. E. and Wilkerson, K. (2005) 'Congress on the Internet: Messages on the Homepages of the US House of Representatives, 1996 and 2001', Journal of Computer Mediated Communication, 10 (2): 24 pp.

http://www.jcmc.indiana.edu/vol10/Issue2/jarvis.html

Johnson, D. W. (2004) Congress Online: Bridging the Gap Between Citizens and

Their Representatives, New York: Routledge.

Kendall, K. E. and Paine, S. C. (1995) 'Political Images and Voting Decisions', in K

L. Hacker (ed.) Candidate Images in Presidential Elections, Westport, CT: Praeger.

King, A. (2002) 'Do Leaders’ Personalities Really Matter', in A. King (ed.) Leaders'

Personalities and the Outcomes of Democratic Elections, Oxford: Oxford University Press.

Lilleker, D. G. and Negrine, R. (2002) 'Not Big Brand Names but Corner Shops:

Marketing Politics to a Disengaged Electorate', Journal of Political Marketing, 2 (1):

$55-75$. 
Livingstone, S. (2003) 'On the Challenges of Cross-National Comparative Media Research', European Journal of Communication, 18 (4): 477-500.

McAllister, I. (forthcoming 2007). 'The Personalization of Politics', in R. J. Dalton and H. D. Klingemann (eds.) Oxford Handbook of Political Behavior, New York: Oxford University Press.

Margolis, M., Resnick, D. and Wolfe, J. D. (2001) 'Party Competition on the Internet in the United States and Britain', Harvard International Journal of Press/ Politics, 4 (4): $24-47$.

Mayhew, D R. (1974) Congress: the Electoral Connection, New Haven, CT: Yale University Press.

Medvic, S. K. (2001) Political Consultants in US Congressional Elections, Columbus, OH: Ohio State University Press.

Miller, H. (1995) 'The Presentation of Self in Electronic Life: Goffman on the Internet', a paper presented at Embodied Knowledge and Virtual Space Conference, Goldsmiths College, University of London, June.

Miller, H. (1998) 'The Presentation of Self in WWW Home Pages', a paper presented at IRSIS Conference, University of Bristol, March 25-27.

Mughan, A. (2000) Media and the Presidentialization of Parliamentary Elections, Basingstoke: Palgrave.

Norris, P. (2000) A Virtuous Circle: Political Communications in Postindustrial Societies, Cambridge: Cambridge University Press.

Norton, P. and Wood, D M. (1993) Back From Westminster: British Members of Parliament and their Constituents, Lexington, KN: University Press of Kentucky. Pels, D. (2003) 'Aesthetic Representation and Political Style: Re-balancing Identity and Difference in Media Democracy', in J. Corner and D. Pels (eds.) Media and the

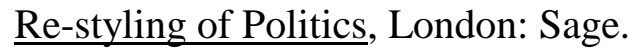


Peters, B Guy. (1998) Comparative Politics: Theory and Methods, Basingstoke:

Palgrave.

Power, G. (1998) Representatives of the People? The Constituency Role of MPs,

Fabian Society Discussion Paper 45, London: College Hill Press.

Radice, L., Vallance, E. and Willis, V. (1987) Member of Parliament: The Job of a

Backbencher, Basingstoke: Macmillan.

Rush, M. (2001) The Role of the Member of Parliament Since 1868: From Gentlemen

to Players, Oxford: Oxford Univeristy Press.

Schudson, M. (2004) 'Notes on Scandal and the Watergate Legacy', American

Behavioural Scientist, 47 (9):1231-1238.

Schutz, A. (1995) 'Entertainers, experts, or Public Servants? Politicians' Self-

presentation on Television Talkshows', Political Communication, 12 (2): 211-222.

Sigelman, L. (2001) The Presentation of Self in Presidential Life: onstage and

Backstage with Johnson and Nixon', Political Communication, 18 (1): 1-22.

Street, J. (2003) 'The Celebrity Politician: Political Style and Popular Culture', in J.

Corner and D. Pels (eds.) Media and the Restyling of Politics: Consumerism,

Celebrity and Cynicism, London and Thousand Oaks, CA: Sage.

Stromer-Galley, J. (2000) 'On-line Interaction and Why Candidates Avoid it', Journal of Communication, 50 (2): 111-132.

Ward, S. and Gibson, R. (2003) 'Online and On Message? Candidate Websites in the 2001 General Election Campaign', The British Journal of Politics and International Relations, 5 (2): 188-205.

Wattenberg, M. P. (1996) The Decline of American Political Parties 1952-1994,

Cambridge, MA: Harvard University Press. 
Table 1: Websites with a prominent greeting

\begin{tabular}{lccc} 
& $\begin{array}{c}\text { Home pages with } \\
\text { welcome/greeting }\end{array}$ & $\begin{array}{c}\text { Home pages with no } \\
\text { welcome/greeting }\end{array}$ & Total \\
\hline US House members & 27 & 23 & 50 \\
& $54.0 \%$ & $46.0 \%$ & $100.0 \%$ \\
UK MPs & & & \\
& 35 & 15 & 50 \\
& $70.0 \%$ & $30.0 \%$ & $100.0 \%$ \\
\hline
\end{tabular}

Table 2: Websites with a prominent invitation to sign-up for information

\begin{tabular}{lccc} 
& $\begin{array}{c}\text { Invite to sign-up for } \\
\text { information }\end{array}$ & $\begin{array}{c}\text { No invite to sign-up for } \\
\text { information }\end{array}$ & Total \\
\hline US House members & 39 & 11 & 50 \\
UK MPs & $78.0 \%$ & $22.0 \%$ & $100.0 \%$ \\
& 14 & 36 & 50 \\
& $28.0 \%$ & $72.0 \%$ & $100.0 \%$ \\
\hline
\end{tabular}

Table 3: Websites displaying news on representatives' achievements

\begin{tabular}{l|ccc}
\hline & $\begin{array}{c}\text { News on Representative's } \\
\text { activities }\end{array}$ & $\begin{array}{c}\text { No news on Representative's } \\
\text { activities }\end{array}$ & Total \\
\hline US House members & 44 & 6 & 50 \\
& $88.0 \%$ & $12.0 \%$ & $100.0 \%$ \\
UK MPs & 28 & 22 & 50 \\
& $56.0 \%$ & $44.0 \%$ & $100.0 \%$ \\
\hline
\end{tabular}

Table 4: Websites displaying information on the representatives' activities in the legislature

\begin{tabular}{lccc} 
& $\begin{array}{c}\text { Committee member, } \\
\text { legislative involvement }\end{array}$ & $\begin{array}{c}\text { No membership of committees or } \\
\text { legislative involvement }\end{array}$ & Total \\
\hline US House members & 46 & 4 & 50 \\
& $92.0 \%$ & $8.0 \%$ & $100.0 \%$ \\
UK MPs & 33 & 17 & 50 \\
& $66.0 \%$ & $34.0 \%$ & $100.0 \%$ \\
\hline
\end{tabular}


Table 5: Websites displaying information on the representatives' education and experience

\begin{tabular}{lccc}
\hline & $\begin{array}{c}\text { Mention of education and } \\
\text { experience }\end{array}$ & $\begin{array}{c}\text { No mention of education and } \\
\text { experience }\end{array}$ & Total \\
US House members & 50 & & 50 \\
UK MPs & $100.0 \%$ & 9 & $100.0 \%$ \\
& 41 & $18.0 \%$ & 50 \\
\hline
\end{tabular}

Table 6: Websites displaying information on the representatives' awards and honours

\begin{tabular}{lccc} 
& $\begin{array}{c}\text { Mention of awards and } \\
\text { honours }\end{array}$ & $\begin{array}{c}\text { No mention of awards and } \\
\text { honours }\end{array}$ & Total \\
\hline US House members & 18 & 32 & 50 \\
UK MPs & $36.0 \%$ & $64.0 \%$ & $100.0 \%$ \\
& 6 & 44 & 50 \\
\hline
\end{tabular}

Table 7: Websites displaying information on the representatives' activities and involvement in the community

\begin{tabular}{lccc}
\hline & $\begin{array}{c}\text { Evidence of community } \\
\text { involvement }\end{array}$ & $\begin{array}{c}\text { No evidence of community } \\
\text { involvement }\end{array}$ & Total \\
\hline US House members & 44 & 6 & 50 \\
& $88.0 \%$ & $12.0 \%$ & $100.0 \%$ \\
UK MPs & 38 & 12 & 50 \\
& $76.0 \%$ & $24.0 \%$ & $100.0 \%$ \\
\hline
\end{tabular}

Table 8: Websites displaying information on the representatives' local roots

\begin{tabular}{lccc}
\hline & Mention of local roots & No mention of local roots & Total \\
\hline US House members & 39 & 11 & 50 \\
& $78.0 \%$ & $22.0 \%$ & $100.0 \%$ \\
UK MPs & 14 & 36 & 50 \\
& $28.0 \%$ & $72.0 \%$ & $100.0 \%$ \\
\hline
\end{tabular}


Table 9: Websites displaying information on the representatives' family

\begin{tabular}{lccc}
\hline & Family Information & No family information & Total \\
\hline US House members & 45 & 5 & 50 \\
UK MP & $90.0 \%$ & $10.0 \%$ & $100.0 \%$ \\
& 29 & 21 & 50 \\
\hline
\end{tabular}

Table 10: Websites displaying information on the representatives' party

identity

\begin{tabular}{lccc} 
& $\begin{array}{c}\text { Party name /symbol } \\
\text { displayed }\end{array}$ & $\begin{array}{c}\text { Party name/symbol not } \\
\text { displayed }\end{array}$ & Total \\
\hline US House members & 2 & 48 & 50 \\
UK MPs & $4.0 \%$ & $96.0 \%$ & $100.0 \%$ \\
& 39 & 11 & 50 \\
& $78.0 \%$ & $22.0 \%$ & $100.0 \%$ \\
\hline
\end{tabular}

\footnotetext{
${ }^{1}$ The author would like to thank John Corner and the anonymous referees for their helpful comments on an earlier draft of this article.

${ }^{2}$ http://www.ipu.org/parline-e/parlinesearch.asp

${ }^{3}$ The 2007 figures are based on an analysis of the web directories for the House of Commons and the House of Representatives (addresses below).

${ }^{4}$ Like Mayhew's study, this article also assumes that elected officials 'are single minded seekers or reelection', for as Mayhew notes, such 'a simple abstract assumption about human motivation' allows speculation 'about the consequences of behavior based on that motivation' (1974: 5).

${ }^{5}$ For a more detailed discussion of differences between MPs and House members, see Mayhew (1974), pp. 20-28.

${ }^{6}$ For the House of Representatives see http://www.house.gov/house/MemberWWW.html and House of Commons http://www.parliament.uk/directories/hciolists/alms.cfm
} 